\title{
Korelasi Pemberian Tugas Rumah Terhadap Prestasi Belajar Mahasiswa Program Studi Diploma 3 Bahasa Jepang Universitas Sam Ratulangi
}

\author{
Ilke Janemralina Moniung \\ ilke_moniung@yahoo.com \\ Fakultas Ilmu Budaya \\ Universitas Sam Ratulangi
}

\begin{abstract}
Homework method is one of the method in gaining understanding. It is a way in increasing the learning result mastery, the phase is important because the lecturer will get a helpful feedback from the students regarding the learning process. A quick task given with a good learning outcome can increase the ability of student in wider, higher and complex learning experience.

A regular task given will give a good attitude and positive way of learning, and eventually will motivate the students to have independent study habit of learning and studying. Therefore, task giving activity still trigger the learning ability of the students. The receiving attitude of students in responding of the task is needed to be focused. The diligent students will adjust to that environment easily while others will not.

The reverse attitude are shown by the lazy students, task given activities will be a burden to them. They reject directly and act without attention. In other words, the diligent students will do the tasks and the lazy student will not do the tasks or even they do the tasks unseriously.

Efforts are needed in improving the Japanese students study achievements one of the efforts is giving the student homework regularly and expecting it can stimulate the students eagerness to study at homework that will increase the study achievement. This research is aimed to find the significance correlation between homework given and study achievement of students who study Japanese.

Data were collected by test, quesionare, interview, observation and dokumentation.

Keyword: Homework, study, achievement
\end{abstract}

\section{Pendahuluan}

Bahasa pada dasarnya merupakan alat komunikasi yang akurat bagi kehidupan umat manusia. Suatu kenyataan yang tidak dapat dipungkiri bahwa dewasa ini semakin dirasakan betapa pentingnya fungsi bahasa sebagai alat komunikasi. Semua aktifitas, manusia menggunakan bahasa sebagai alat komunikasi. Karena disadari bahwa segala interaksi aktifitas dalam masyarakat akan lumpuh tanpa adanya bahasa.

Sebagai alat komunikasi, bahasa digunakan oleh anggota masyarakat penuturnya menjalin hubungan dengan anggota masyarakat lain. Hubungan atau komunikasi itu dapat dapat dilakukan secara perseorangan ataupun secara kelompok. Lebih lanjut, komunikasi 
itu juga memungkinkan seseorang bekerjasama dengan orang lain, membentuk kelompok atau bahkan membentuk suatu masyarakat untuk kepentingan bersama.

Indonesia sebagai negara berkembang terus menjalin hubungan kerjasama dengannegara lain. Untuk hubungan kerjasama dengan negara lain maka diperlukan adanya sarana komunikasi, dalam hal ini bahasa asing memengang peranan penting. Dengan kata lain sebagai alat komunikasi, bahasa dapat dipergunakan sebagai sarana untuk menjalin kerjasama dengan pihak lain. Bahasa juga merupakan saluran perumusan maksud seseorang, melahirkan perasaan, pikiran atau pendapat untuk menjalin hubungan dan menciptakan keakraban dengan orang lain.

Sehubungan dengan ini Tampubolon mengatakan bahwa, bahasa memungkinkan anggota masyarakat menyampaikan hasil-hasil karya mereka kepada sesamanya dan mungkin juga kepada anggota masyarakat lain (1975:3). Bahasa asing disamping berfungsi sebagai alat penghubung antar bangsa juga sebagai alat pemanfaatan ilmu pengetahuan dan teknologi modern untuk pembangunan nasional.

Indonesia sebagai negara berkembang terus berpacu dalam berbagai sektor pembangunan. Untuk hal tersebut menjalain hubungan kerjasama dengan negara lain terutama negara-negara maju untuk mengadakan alih teknologi guna mempercepat pembangunan bangsa demi mencapai tujuan nasional yaitu mewujudkan masyarakat adil dan makmur. Untuk hubungan kerjasama dengan negara-negara lain maka diperlukan adanya sarana komunikasi, dalam hal ini bahasa asing memegang peranan penting. Bahasa asing selain berfungsi sebagai alat penghubung antar bangsa juga sebagai pemanfaatan ilmu pengetahuan dan teknologi modern untuk pembangunan nasional. Hal ini senada dengan yang dikemukakan oleh Giri Kartono (1984:125) bahwa: "Bahasa asing harus dikuasai sedemikian rupa sehingga dapat dipakai sebagai alat untuk membantu mempercepat proses pembangunan bangsa dan negara biarpun secara tidak langsung““.

Dengan melihat pentingnya bahasa asing maka pemerintah Indonesia telah menyelenggarakan pengajaran bahasa asing seperti bahasa Inggris, Jepang, Jerman, Perancis dan Mandarin di SLTA dan Perguruan Tinggi.

Dalam pengajaran bahasa Jepang tercantum tujuan kurikuler dalam kurikulum dan Garis-Garis Besar Program Pengajaran tahun 1986 yaitu: "Mahasiswa memiliki kemampuan berbahasa Jepang agar dapat menyimak, berbicara, membaca dan menulis karangan sederhana dalam bahasa Jepang“. Untuk mencapai tujuan kurikuler pengajaran bahasa Jepang digunakan berbagai metode mengajar, agar interaksi belajar mengajar 
berlangsung secara efektif dan tujuan yang diharapkan dapat tercapai. Seperti yang dikemukakan oleh Moh.Surya (1985:78) bahwa: "Dalam interaksi belajar mengajar, metode mengajar merupakan hal yang menentukan. Demikian pula hasil belajar yang dicapai siswa akan bergantung dari metode mengajar yang dipergunakan oleh dosen ". Diperlukan usaha yang lebih untuk meningkatkan prestasi belajar bahasa Jepang mahasiswa. Salah satu usaha yang dilakukan yaitu dengan memberikan tugas rumah secara berkalan dengan harapan bisa merangsang mahasiswa untuk belajar di rumah sehingga prestasi belajar bahasa Jepang bisa meningkat. Untuk itu seorang dosen diharapkan mampu untuk menggunakan dan memilih metode mengajar. Keberhasilan seorang dosen di depan kelas bukan saja ditentukan oleh penampilannya, akan tetapi dapat dilihat dari segi penggunaan metode yang tepat.

Metode merupakan cara utama yang dipergunakan dalam usaha mencapai tujuan yang diharapkan baik oleh dosen maupun oleh siswa/mahasiswa. Adapun metode-metode yang sering digunakan oleh dosen dalam proses belajar mengajar sebagai berikut:

- Metode Ceramah

- Metode Tanya Jawab

- Metode Diskusi

- Metode Pemberian Tugas rumah

- Metode Resitasi

-Metode Demonstrasi

- Metode Eksperimen
- Metode Sosiodrama dan Bermain Peran

- Metode Belajar dalam Kelompok

- Metode Proyek

- Metode Problem Solving

- Metode Karya Wisata

- Metode Film Strips

- Metode Metode Manusia/resoirce people

( Roestiyah, 1980:67)

Dan salah satu metode mengajar yang sering digunakan oleh dosen adalah metode pemberian tugas rumah. Dosen yang menggunakan metode pemberian tugas rumah tanpa mengetahui bagaimana memberikan tugas rumah yang tepat dan benar dapat mengakibatkan minat smahasiswa terhadap pelajaran tersebut berkurang, tidak ada perhatian dan kesungguhan belajar dari siswa serta dapat mengakibatkan rendahnya mutu pelajaran. Sebaliknya akan terjadi apabila penggunaan didasari pengertian yang mendalam dari pihak dosen, akan memperbesar minat belajar siswa dan akan mempertinggi hasil belajar mereka (Winarno Surakhmad, 1980:24).

Penelitian ini bertujuan untuk mengetahui ada atau tidak ada korelasi yang cukup signifikan antara pemberian tugas rumah dengan prestasi belajar mahasiswa. 


\section{Rumusan Masalah Penelitian}

Masalah dalam penelitian ini dirumuskan sebagai berikut:

Apakah terdapat hubungan yang signifikan antara pemberian tugas rumah terhadap prestasi belajar bahasa Jepang?

\section{Landasan Teori}

\section{Proses Belajar Mengajar}

Belajar mengajar adalah interaksi (memberi dan menerima) atau hubungan timbal balik antara siswa/mahasiswa dengan guru/dosen dan antar sesama siswa/mahasiswa dalam proses belajar mengajar.

Dalam Petunjuk Pelaksanaan Proses Belajar Mengajar (1994:3) pengertian tentang belajar ditulis sebagai berikut: "Belajar adalah proses perubahan sikap dan tingkah laku setelah terjadinya interaksi dengan sumber belajar“. Sumber belajar ini dapat berupa buku, lingkungan, guru/dosen atau sesama teman. Faktor-faktor yang sangat erat hubungannya dengan proses belajar adalah kematangan, penyesuaian diri atau adaptasi, menghafal atau mengingat, pengertian, berpikir dan latihan. Sedangkan istilah mengajar adalah menciptakan situasi yang mampu merangsang mahasiswa untuk belajar. Hal ini tidak harus berupa proses transformasi pengetahuan dosen kepada mahasiswa

\section{Komponen Yang Berpengaruh Dalam Proses Belajar Mengajar}

Suatu proses belajar mengajar dapat berjalan efektif bila seluruh komponen saling mendukung dalam rangka mencapai tujuan. Misalnya mahasiswanya termotivasi, materinya menarik, tujuannya jelas dan hasilnya dapat dirasakan manfaatnya.

Komponen-komponen yang berpengaruh dalam proses belajar mengajar adalah dalam Petunjuk Pelaksanaan Proses Belajar Mengajar (1994:4) ditulis:

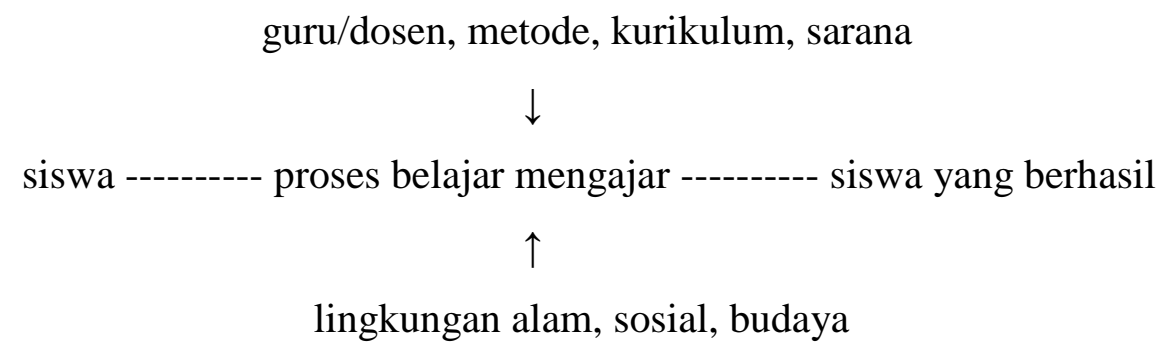


Jadi dalam proses belajar mengajar, dosen membuat perencanaan sedemikian rupa dalam bentuk satuan pengajaran, rencana pengajaran atau satuan bahan dan mengembangkannya dalam interaksi belajar sehingga apa yang menjadi tujuan dapat tercapai.

Untuk itu pula seorang dosen harus dapat mengelola komponen yang ada sehingga dapat meningkatkan hasil proses belajar mengajar.

\section{Pengertian Tugas Rumah}

Tugas merupakan pekerjaan yang harus diselesaikan. Pemberian tugas sebagai suatu metode atau cara mengajar merupakan suatu pemberian pekerjaan oleh dosen kepada mahasiswa untuk mencapai tujuan pengajaran tertentu. Dengan pemberian tugas tersebut mahasiswa belajar mengerjakan tugas. Dalam melaksanakan kegiatan belajar, mahasiswa diharapkan memperoleh suatu hasil ialah perubahan tingkah laku tertentu sesuai dengan tujuan yang diharapkan.

Pemberian tugas adalah metode penyajian bahan dimana dosen memberikan tugas tertentu agar mahasiswa melakukan belajar. Metode ini diberikan karena dirasakan bahan mata kuliah terlalu banyak, sementara waktu sedikit. Artinya, banyaknya bahan yang tersedia dengan waktu yang kurang seimbang. Agar bahan mata kuliah selesai sesuai batas waktu yang ditentukan, maka metode inilah yang biasa digunakan.

Tugas tidak sama dengan pekerjaan rumah, tetapi jauh lebih luas dari itu bisa dilaksanakan di rumah, di sekolah, di perpustakaan, dan tempat lainnya. Tugas merangsang anak untuk aktif belajar, baik secara individual maupun kelompok. Karena itu, tugas dapat diberikan secara individual atau dapat secara kelompok.

Berdasarkan uraian di atas dapat disimpulkan bahwa pemberian tugas adalah suatu metode atau cara yang digunakan dosen untu dapat membelajarkan mahasiswa dalam upaya meningkatkan hasil belajar.

\section{Pemberian Tugas Rumah}

Pemberian tugas rumah atau dikenal dengan sebutan pekerjaan rumah (PR) dikatakan sebagai suatu pemberian pekerjaan oleh dosen kepada mahasiswa untuk mencapai tujuan pengajaran tertentu. Dengan pemberian tugas tersebut mahasiswa belajar mengerjakan tugas untuk meningkatkan hasil belajar. Namun kenyataannya ada mahasiswa yang patuh mengerjakan PR dan tak sedikit pula yang tidak mengerjakannya atau bahkan mengabaikannya.PR juga merupakan alat komunikasi antara orang tua dan dosen di mana PR mewakili diri dosen. PR yang guru berikan bukan hanya sekedar untuk 
mengisi waktu luang atau dibuat sangat sulit dengan harapan agar orang tua banyak berperan aktif dalam penggarapannya. Pekerjaan rumah atau yang lazim disebut PR dalam bahasa Inggris "homework" yang artinya mengerjakan pekerjaan rumah. Pekerjaan rumah adalah sebuah tugas atau pekerjaan tertentu baik tertulis atau lisan yang harus dikerjakan di luar jam kuliah (terutama di rumah) berkaitan dengan pelajaran yang telah disampaikan guru untuk meningkatkan penguasaan konsep atau keterampilan dan memberikan pengembangan. Berdasarkan uraian di atas dapat disimpulkan bahwa pekerjaan rumah adalah tugas yang diberikan guru kepada mahasiswa, yang wajib dikerjakan oleh mahasiswa di rumah baik berupa tertulis atau lisan dengan mendapat perhatian dari orang tuanya.

Pekerjaan rumah dapat diberikan guna melengkapi pilihan pengejaran bagi mahasiswa yang tertinggal dalam pengembangan keterampilan. Bila tujuan pekerjaan rumah adalah untuk memberikan pemulihan, maka memberikan pekerjaan yang terselubung bagi seluruh siswa akan nyaris dapat dia benarkan, karena mahasiswa melangkah maju dalam kecepatan berbeda. Pekerjaan rumah memberikan peluang emas bagi perorangan, walaupun ia mengisyaratkan perencanaan sebelumnya. Walaupun hanya berupa membaca, menjawab esai pendek, dan masalah latihan akan menjadikan banyak pekerjaan rumah.

\section{Prestasi Belajar}

Prestasi belajar merupakan hasil belajar yang dicapai berupa penguasaan atau ketrampilan yang dikembangkan oleh mata kuliah yang lazimnya ditunjukkan dengan nilai tes atau angka yang diberikan dosen.Hasil belajar selalu menjadi topik yang menarik dalam dunia pendidikan. Para orang tua dan dosen serta mahasiswa bekerja sama agar mahasiswa mendapat hasil belajar yang baik bahkan memuaskan. Upaya yang dilakukannya dengan mengetahui faktor-faktor yang mempengaruhi hasil belajar.

Sebelum membicarakan faktor-faktor yang mempengaruhi hasil belajar, sesuatu yang telah dicapai oleh siswa dalam kegiatan belajar atau proses belajar sering disebut dengan hasil. Pada proses pendidikan menghasilkan hasil utama dan hasil sampingan. Hasil utama adalah hasil belajar yang dicapai sesuai dengan tujuan pembelajaran, sedangkan hasil sampingan adalah hasil yang dicapai dalam proses pendidikan walaupun tidak direncanakan dalam tujuan pembelajaran. 
Hasil belajar merupakan perubahan perilaku siswa akibat belajar. Belajar merupakan proses dalam diri individu yang berinteraksi dengan lingkungan untuk mendapatkan perubahan dalam perilakunya. Winkel mendefinisikan belajar adalah aktivitas mental/psikis yang berlangsung dalam interaksi aktif dengan lingkungan yang menghasilkan perubahan-perubahan dalam pengetahuan, keterampilan dan sikap.

Oemar Hamalik dalam bukunya Kurikulum dan Pembelajaran mengemukakan bahwa belajar adalah modifikasi atau memperteguh kelakuan melalui pengalaman (Learning is defined as the modification or strengthening of behavior through experiencing). Berdasarkan beberapa definisi di atas, dapat disimpulkan belajar adalah proses untuk membuat perubahan dalam diri siswa dengan cara berinteraksi dengan lingkungan untuk mendapatkan perubahan dalam aspek kognitif, afektif, dan psikomotorik. Belajar dilakukan untuk mengusahakan adanya perubahan tingkah laku pada individu yang belajar. Perubahan tingkah laku itu merupakan perolehan yang menjadi hasil belajar. Hasil belajar menurut Abdurrahman dan Juliah adalah segala sesuatu yang menjadi milik siswa atau kemampuan yang diperoleh anak setelah melalui kegiatan belajar yang dilakukannya. Menurut Winkel hasil belajar adalah perubahan yang mengakibatkan manusia berubah dalam sikap dan tingkah lakunya. Aspek perubahan itu mengacu kepada taksonomi tujuan pengajaran yang dikembangkan oleh Bloom, Simpson dan Harrow mencakup aspek kognitif, afektif dan psikomotorik.

\section{Tujuan Penelitian}

Penelitian ini bertujuan untuk mendapatkan gambaran mengenai pelaksanaan pemberian tugas rumah, mengetahui bagaimana korelasi pemberian tugas rumah terhadap prestasi belajar dan mengukur bagaimana efektivitas dari pemberian soal-soal latihan dalam rangka meningkatkan prestasi belajar. di Prodi D-3 Bahasa Jepang Fakultas Ilmu Budaya

\section{Manfaat Penelitian}

Penelitian ini diharapkan dapat bermanfaat sebagai bahan masukkan kepada dosen bahasa Jepang untuk meningkatkan kemampuan mengajar dan membantu mahasiswa dalam membuat dan menyelesaikan soal-soal latihan untuk mendapatkan hasil belajar yang lebih baik. 


\section{Tempat Penelitian}

Penelitian ini dilaksankaan di Prodi D-3 Bahasa Jepang Fakultas Ilmu Budaya Universitas Sam Ratulangi.

\section{Metode Penelitian}

Penelitian ini menggunakan metode deskriptif menurut Suharsimi (1989:291) untuk mengumpulkan informasi mengenai status suatu gejala yang ada dan metode korelasi Suharsimi (1991:27) untuk mengetahui hubungan dua fenomena atau lebih.

\section{Populasi}

Populasi dalam penelitian ini adalah seluruh mahasiswa Prodi D-3 Bahasa Jepang Fakultas Ilmu Budaya.

\section{Proses Belajar Mengajar}

Belajar mengajar adalah interaksi (memberi dan menerima) atau hubungan timbal balik antara siswa/mahasiswa dengan guru/dosen dan antar sesama siswa/mahasiswa dalam proses belajar mengajar.

Dalam Petunjuk Pelaksanaan Proses Belajar Mengajar (1994:3) pengertian tentang belajar ditulis sebagai berikut: "Belajar adalah proses perubahan sikap dan tingkah laku setelah terjadinya interaksi dengan sumber belajar “. Sumber belajar ini dapat berupa buku, lingkungan, guru/dosen atau sesama teman. Faktor-faktor yang sangat erat hubungannya dengan proses belajar adalah kematangan, penyesuaian diri atau adaptasi, menghafal atau mengingat, pengertian, berpikir dan latihan. Sedangkan istilah mengajar adalah menciptakan situasi yang mampu merangsang mahasiswa untuk belajar. Hal ini tidak harus berupa proses transformasi pengetahuan dosen kepada mahasiswa

\section{Komponen Yang Berpengaruh Dalam Proses Belajar Mengajar}

Suatu proses belajar mengajar dapat berjalan efektif bila seluruh komponen saling mendukung dalam rangka mencapai tujuan. Misalnya mahasiswanya termotivasi, materinya menarik, tujuannya jelas dan hasilnya dapat dirasakan manfaatnya.

Komponen-komponen yang berpengaruh dalam proses belajar mengajar adalah dalam Petunjuk Pelaksanaan Proses Belajar Mengajar (1994:4) ditulis: 
guru/dosen, metode, kurikulum, sarana

siswa proses belajar mengajar siswa yang berhasil

lingkungan alam, sosial, budaya

Jadi dalam proses belajar mengajar, guru/dosen membuat perencanaan sedemikian rupa dalam bentuk satuan pengajaran, rencana pengajaran atau satuan bahan dan mengembangkannya dalam interaksi belajar sehingga apa yang menjadi tujuan dapat tercapai. Untuk itu pula seorang guru/dosen harus dapat mengelola komponen yang ada sehingga dapat meningkatkan hasil proses belajar mengajar.

\section{Pemberian Tugas Rumah}

Metode pemberian tugas rumah merupakan salah satu metode untuk memberikan pengalaman belajar yang dapat meningkatkan cara belajar yang lebih baik dan memantapkan penguasaan perolehan hasil belajar. Pemberian tugas rumah merupakan tahap yang penting dalam mengajar, karena dalam pemberian tugas itu dosen memperoleh umpan balik tentang kualitas hasil belajar mahasiswa.

Untuk mempersiapkan kegiatan-kegiatan untuk mencapai tujuan pengajaran, dipersiapkan juga metode pengajaran yang akan digunakan dosen. Pemilihan dan penggunaan metode pengajaran dengan benar dapat membantu pembelajar dan pengajar merealisasikan kegiatan pengajaran berhasil dan mencapai tujuan yang diharapkan.

Salah satu metode yang digunakan untuk mencapai tujuan pelajaran adalah metode pemberian tugas rumah. Alipandie Imansjah dalam buku Didakti Metodik Pendidikan Umum menulis:“" Metode pemberian tugas rumah yaitu cara mengajar yang dilakukan guru dangan jalan memberi tugas kepada siswa/mahasiswa untuk mengerjakan sesuatu diluar jam pelajaran" (1984 : 91). Seperti kita ketahui, waktu belajar di sekolah terbatas, jadi untuk meningkatkan kualitas pelajaran, diperlukan banyak latihan dan praktek.Menurut Abdul Gafur: "Setelah siswa/mahasiswa diberi informasi mengenai pengetahuan yang harus mereka miliki, mereka hendaknya diberi kesempatan untuk berlatih atau mempraktekkan pengetahuan atau ketrampilan yang diharapkan dapat dimiliki oleh mereka setelah selesai belajar"(1984 : 94).

Latihan-latihan pemberian tugas rumah membantu siswa/mahasiswa untuk melatih materi pelajaran yang telah didapat dan diajarkan. Menurut Roestiyah:"Pemberian tugas 
digunakan dengan tujuan agar siswa memiliki hasil belajar yang lebih mantap, karena siswa melaksanakan latihan-latihan selama melakukan tugas sehingga pengalaman siswa dalam mempelajari sesuatu dapat lebih terintegrasi" (1980:15).

Pemberian tugas rumah sebagai aktivitas untuk memecahkan persoalan sambil membaca, menjawab pertanyaan dan mengamat-amati apa yang belum mereka ketahui. Jadi fungsi dari pengajaran dengan menggunakan metode pemberian tugas rumah adalah membantu mengatur aktivitas siswa/mahasiswa sambil menolong mereka menggunakan literatur, peralatan, dan lain-lain.Untuk lebih baik mengorganisir pemberian tugas rumah dan untuk mencapai tujuan yang telah ditentukan, guru harus mengetahui ciri-ciri metode pemberian tugas rumah adalah membantu mengatur aktivitas siswa sambil menolong mereka menggunakan literatur, peralatan, dan lain-lain.Untuk itu dosen perlu mengetahui ciri-ciri metode pemberian tugas rumah, keuntungan dan kelemahan dari metode tersebut.

\section{Ciri-ciri metode pemberian tugas rumah}

Terdiri dari 3 tahap yaitu :

- Dosen memberi tugas

- Mahasiswa melaksanakan tugas

- Mahasiswa melaporkan hasil pelaksanaan tugas

\section{A. Cara dosen memberikan tugas}

Ada banyak pilihan yang harus dipersiapkan untuk memberikan tugas rumah. Yang harus dipersiapkan untuk memberikan tugas rumah adalah menjelaskan dengan jelas memberikan tugas rumah, harus diiringi dengan penjelasan bagaimana menyelasaikan dan memecahkan kesulitan-kesulitan yang ada. Penjelasan yang kurang jelas dapat menyulitkan siswa/mahasiswa mengerjakan tugas rumah yang diberikan.

Materi pemberian tugas rumah yang diberikan oleh seorang dosen melingkupi:

a. Materi yang mendorong mahasiswa mencoba sendiri, mencari sendiri, menyelesaikan sendiri dan melaporkan hasilnya.

b. Materi harus berhubungan dengan pelajaran yang diberikan.Harus menarik minat mahasiswa dan sesuai dengan kemampuan mereka. Materi itu adalah pelaksanaan dan ajakan dari kenyataan dalam masyarakat. 
Pemberian tugas rumah tidak boleh terlalu banyak, harus diingat bahwa mereka juga harus belajar mata pelajaran yang lain. Pemberian tugas rumah yang jelas dan terbatas akan rumah membuat siswa bekerja dengan baik dan menyenanginya.

Sedangkan pemberian tugas yang terlalu banyak dapat menggangu perkembangan fisik dan spiritual pada usia mereka. Dan mungkin juga menjadi sebab kesedihan dari siswa dan kemudian tidak lagi menyenangi mata kuliah itu.

\section{B. Mahasiswa mengerjakan pemberian tugas rumah}

Dosen memberikan tugas rumah, mahasiswa mengerjakannya sambil belajar sendiri atau sambil mencari buku-buku yang sesuai dengan tujuan yang telah diajarkan oleh dosen.

\section{Mahasiswa mempertanggungjawabkan tugas rumah yang telah dikerjakan}

Ketika mereka telah selesai mengerjakan tugas rumah, mereka harus membuat laporan yang bentuknya telah ditentukan sesuai dengan fungsi dari tujuan, laporan itu berupa tes lisan, menjawab pertanyaan, diskusi atau menghafal dengan singkat dan lainlain. Bagaimanapun juga mahasiswa harus mempertanggungjawabkan tugas mereka yang sudah dikerjakan.

Aktivitas mengajar dalam tahap ini adalah mempersiapkan instrumen penilaian, agar supaya dapat menilai laporan-laporan mahasiswa dan memberikan penjelasan objektif atas usaha mereka dalam mengerjakan tugas rumah.

Penilaian ini sangat baik sebab mereka dapat menumbuhkan suatu motivasi yang baik untuk bekerja dan meningkatkan keinginan belajar.

\section{Kelemahan metode pemberian tugas rumah}

- Mahasiswa mungkin hanya meniru pekerjaan teman

- Orang lain yang mengerjakan pekerjaan tersebut

- Apabila tugas sering diberikan, lebih-lebih lagi apabila tugas itu sukar maka ketenangan mental mahasiswa terganggu.

\section{Keuntungan/kelebihan metode pemberian tugas rumah}

- Mahasiswa menjadi terbiasa mengisi waktu senggangnya

- Mahasiswa mempertanggungjawabkan hasil pekerjaannya kepada dosen

- Melatih mahasiswaberpikir kritis, tekun, giat dan rajin belajar

- Akan lebih lama untuk diingat 


\section{Prestasi Belajar}

Prestasi belajar adalah dua kata yang digabungkan dan menjadi suatu pengertian yangsangat populer yang digunakan dalam proses belajar mengajar.

Prestasi belajar merupakan hasil perubahan dalam tingkah laku yang meliputi 3 domein yaitu kognitif, afektif dan psikomotor. Dengan demikian prestasi belajar itu merupakan produk dari sebuah proses yang bersangkut paut dengan pengetahuan,ketrampilan dan sikap. Proses yang dimaksud disini yaitu perbuatan belajar. Seseorang tidak mungkin menguasai suatu materi dari suatu bidang studi jika tidak dilakukan kegiatan belajar.

Dalam perolehan prestasi yang lebih baik pandangan di atas dinilai sangat tepat.Prestasi belajar diartikan sebagai hasil yang dicapai dan dilaksanakan setelahmempelajari sesuatu di sekolah/perguruan tinggi dalam kurun waktu tertentu.

Seperti yang dikemukakan oleh Hamalik (1990:34) bahwa: “ Prestasi belajar adalah suatu hasil yang dicapai melalui perbuatan belajar ". Lebih lanjut, prestasi belajar menurut Turang (1980 : 40) adalah sebagai berikut: "Prestasi belajar adalah penampakan tingkat kemampuan belajar dalam hal ini siswa/mahasiswa yang berprestasi akan lebih menguasai, lebih kritis dan lebih trampil dalam menyelesaikan tugas serta mempunyai nilai yang lebih tinggi daripada yang lain “.

Menurut pendapat Nurtain dan Andi.(1979:4) bahwa:"Prestasi belajar itu apa yang dikuasai atau yang dicapai oleh individu yang telah belajar tertentu dalam waktu tertentu "Untuk mencapai tujuan yang lebih baik, maka seorang mahasiswa harus berusaha terus untuk mencari tahu sesuatu yang belam mereka ketahui melalui cara-cara belajar yang efektif, melalui kegiatan-kegiatan ekstra kurikuler yang menunjang keberhasilan belajar, bahkan melalui pembinaan dari dosen.

Jadi prestasi belajar ini hanya dapat berhasil adalah karena aktivitas mahasiswa itu sendiri. Semua hasil belajar yang diperoleh adalah berkat kemampuan yang diperoleh melalui keaktifannya sendiri. Dan bukan merupakan sekedar hadiah atas keberhasilan mereka dalam mencapai tujuan belajarnya tetapi juga sebagai kepuasan dalam diri siswa itu sendiri setelah meraih sukses atau usaha-usaha yang dilakukan.

Dari pendapat-pendapat di atas dapat disimpulkan bahwa prestasi belajar adalah hasil belajar yang diukur dengan angka-angka. Dapat disimpulkan bahwa prestasi belajar adalah hasil belajar yang dicapai atau tingkat penguasaan mahasiswa melakukan kegiatan belajarnya yang diukur dengan angka-angka. Dan untuk mengetahui prestasi belajar siswa 
atau mahasiswa dapat dilihat dalam raport atau KHS yang dimiliki. Faktor-faktor yang mempengaruhi prestasi belajar.

Menurut Slameto (1991:56) faktor-faktor yang mempengaruhi prestasi belajar di golongkan menjadi dua golongan yaitu faktor internal dan faktor eksternal.

- Faktor internal yang meliputi:

1) Faktor jasmaniah seperti kesehatan dan cacat tubuh.

2) Faktor psikologi seperti intelegensi, perhatian, minat, bakat, motif, kematangan dan Kesiapan.

3) Faktor kelelahan baik jasmani maupun rohani.

- Sedangkan faktor eksternal meliputi :

1) Faktor keluarga seperti cara mendidik, relasi antar anggota, suasana rumah, keadaan ekonomi keluarga, pengertian orang tua dan latar belakang kebudayaan.

2) Faktor sekolah yaitu metode mengajar, kurikulum, relasi guru dengan siswa, relasi mahasiswa dengan mahasiswa, disiplin kampus, standart mata kuliah di atas ukuran, keadaan gedung, metode belajar dan tugas di rumah.

3) Faktor masyarakat seperti kegiatan siswa dalam masyarakat, mass media, teman bergaul, bentuk kehidupan masyarakat.

Faktor-faktor ini merupakan usaha yang dilakukan pada pokoknya berkisar pemberian individual menurut kebutuhan dan perbedaan masing-masing.

\section{Kesimpulan}

Setelah menyampaikan penjelasan maka penulis membuat beberapa simpulan sebagai berikut:

- Pemberian tugas rumah ditentukan oleh cara atau strategi dosen mengajar, sikap mahasiswa terhadap tugas tersebut, perhatian dan dukungan orang tua.

- Pemberian tugas rumah adalah sebuah metode pengajaran untuk melatih mata kuliah yang telah dipelajari dengan menggunakan waktu luang yang ada.

- Pemberian tugas rumah adalah salah satu cara yang dapat mempengaruhi hasil belajar mahasiswa.

- Pemberian tugas rumah perlu diatur intensitasnya agar dapat membelajarkan mahasiswa, sikap malas mahasiswa dalam mengerjakan tugas yang diberikan hendaknya diberikan perhatian yang lebih serta dukungan orang tua perlu ditingkatkan. 
- Pemberian tugas rumah yang tidak dipersiapkan dengan baik dapat menghambat atau mempersulit mahasiswa dalam mengerjakannya, lebih khusus pemberian tugas rumah bahasa Jepang.

\section{Daftar Pustaka}

Arikunto, Suharsimi. 1993. Prosedur Penelitian Suatu kajian Pendekatan Praktik. Jakarta; PT.Rineka Cipta.

Departemen Pendidikan dan Kebudayaan, 1994. Petunjuk Pelaksana PBM. Jakarta

Gafur, Abd. 1984. Disain Suatu Pendekatan Sistimatis Penyusunan Pola dasar Kegiatan Belajar Mengajar. Solo : Tiga Serangkai.

Hamalik, Oemar. 1990. Metode dan Kesulitan-Kesulitan Belajar. Bandung. Tarsito

Mulyo, Sugito. 1979. Fungsi Dan Sikap Bahasa. Nusa Indah.

Roestiyah, Yumiati. 1985. Strategi Belajar Mengajar. Jakarta : Bina Akasara.

Slameto. 1991. Belajar dan Faktor-Faktor yang Mempengaruhinya. Jakarta Rineka Cipta.

Winarno, Surakhmad. 1980. Pengantar Interaksi Belajar Mengajar Dasar Dan Teknik Metodologi Pengajaran. Bandung: Tarsito 